\title{
Solution of integration tasks in enterprise management information systems
}

\author{
Valerij Yu. Vahrushev
}

Dean, Faculty of Automation and Computing Machines

Vyatka State University

Address: 36, Moskovskaya Street, Kirov, 610000, Russian Federation

E-mail:vahrushev@vyatsu.ru

\section{Elena V. Bogomolova}

Leading Programming Engineer, LEPSE Company

Post-graduate, Department of Automatics and Telemechanics, Vyatka State University

Address: 36, Moskovskaya Street, Kirov, 610000, Russian Federation

E-mail:elenaoops@mail.ru

\section{Anna M. Lanskih}

Associate Professor, Department of Automatics and Telemechanics

Vyatka State University

Address: 36, Moskovskaya Street, Kirov, 610000, Russian Federation

E-mail: usr00221@vyatsu.ru

\section{Yurij V. Lanskih}

Associate Professor, Department of Automatics and Telemechanics

Vyatka State University

Address: 36, Moskovskaya Street, Kirov, 610000, Russian Federation

E-mail:lyuv@inbox.ru

\section{Andrej V. Luppov}

Associate Professor, Department of Automatics and Telemechanics

Vyatka State University

Address: 36, Moskovskaya Street, Kirov, 610000, Russian Federation

E-mail: dei123@mail.ru

\section{Anna V. Malysheva}

Lecturer, Department of Automatics and Telemechanics

Vyatka State University

Address: 36, Moskovskaya Street, Kirov, 610000, Russian Federation

E-mail:annyml@mail.ru

\section{Natalya A. Shmakova}

Senior Lecturer, Department of Automatics and Telemechanics

Vyatka State University

Address: 36, Moskovskaya Street, Kirov, 610000, Russian Federation

E-mail: shmakova.natalya@mail.ru

\section{Abstract}

The authors consider the problems of constructing systems of accounting, management and analysis of a company. One of the most cost-effective ways to build such systems is the integration of legacy, acquired and developed components on a middleware base, which can be characterized as a technological platform for integration.

Consideration is given to the formalization of principles for creation of such platform software. These principles are formed similarly to the principles of forming a microprogram processor control unit. We are shown how to develop a software platform that makes it possible to organize the launch of procedures for processing, visualization, data exchange by a schedule or by user request, using the microprogram processor control unit as a formal model. The totality of the information and software that acts as a platform is decomposed into instructions memory, metacommand memory, the instruction memory controller and metacommand memory controller. 
A document management system is considered as one of the options of platform software. The electronic document management system for the exchange of information is protected by digital signature. It facilitates integration between information subsystems of reference, accounting and other purposes. This practice is called EDMS-bus.

Within the theoretical formulation of the problem the authors considered the informational domain model as a set of business processes performed in it. The automation of activity in the subject field amounts to forming a set of automated business processes, whose power is determined by the functionality of the implemented information system, and which cover to the maximum extent a set of business processes of the subject area. Examination is made of cases of overlapping sets of legacy information systems business processes and of implemented information systems business processes.

Key words: enterprise management system, information model, electronic document management system, microprogram control unit, business process, middleware.

Citation: Vahrushev V.Yu., Bogomolova E.V., Lanskih A.M., Lanskih Yu.V., Luppov A.V., Malysheva A.V., Shmakova N.A. (2016) Solution of integration tasks in enterprise management information systems. Business Informatics, no. 1 (35), pp. 37-44. DOI: 10.17323/1998-0663.2016.1.37.44.

\section{Introduction}

$\mathrm{F}$ ormation of enterprise information management systems is a necessary condition for improving the performance efficiency of enterprises in various areas. A specific feature for this is to drive cost savings to the maximum during introduction of new and updated old information systems and to use existing developments to the extent possible.

Corporate enterprise applications cannot exist separately. In integration of applications, IT developers need to ensure reliability of the data transmission network, provide an acceptable data rate, take into account the application differences, and make it possible to adapt to alteration of merged applications. To ensure the above requirements, the following basic approaches are identified: file transfer, shared database, remote procedure invocation, messaging [1].

The approach addressed by the authors is an alternative approach which rejects introduction of a single information system which can fully satisfy all the information needs of the data domain given that for large enterprise information systems it is often impossible to find software that would cover the solution of all existing business tasks. The integration problems of heterogeneous information system modules, data porting between subsystems of the information systems, configuring information subsystems to develop additional information system components are solved using the aforementioned approaches. In practice, the solution of such problems at large enterprises in many cases is unique and specific, despite of a large selection of ready-made solutions for application integration using middleware proposed by developers of large and expensive enterprise systems (IBM, MS Biztalk, SAP, Oracle and others.). Replacement of properly functioning enterprise subsystems of various platforms with a multipurpose ERP system is not always justified due to possible overpayment for excessive functionality. In addition, special offers can successfully solve the problem of narrow-profile business tasks. Experience in solving problems of accounting, analytics, information exchange and integration of enterprise information subsystems makes it possible to put forward formal information and structural platform-supported models for effective solution of the enterprise subsystem integration tasks.

\section{Theoretical statement of the problem}

The authors have already addressed a formal characterization of the synchronization problem of reference information from several enterprise information subsystems [2].

Let us form an information model of the domain area as a set of business processes which will be conditionally defined as "idealized":

$$
O F=\left\{B P_{i}\right\} .
$$

Consequently, the information model of the information system available at the time of statement of the automation problem ('as is' model) can be presented as a set of real system-supported business processes: 


$$
I S^{\prime}=\left\{B P_{i}^{\prime}\right\}
$$

The solution of the automation problem should result in obtaining an information system whose information model will be also presented as a new set of business processes (the 'to be' model), which, in general, is not consistent with idealized ones:

$$
I S^{\prime \prime}=\left\{B P_{i}^{\prime \prime}\right\} \text {. }
$$

With regard to each business process $B P_{i}^{\prime \prime}$ it is worthy of note that it is identical to the initial one $B P_{i}^{\prime}$, if not subject to changes in the course of solving the automation problem, and, otherwise, is not identical to the initial one.

Each subsystem of the information system computerizes some subset of the set of computerized business processes:

$$
I S S_{j}^{\prime \prime}=\left\{B P_{i}^{j \prime \prime}\right\}
$$

In the optimal case, the subsystem functions disjoint, making it possible to entirely cover all functional requirements for the introduced system:

$$
\begin{gathered}
\bigcap_{j} B P_{i}^{j \prime \prime}=\varnothing \\
\bigcup_{j} B P_{i}^{j^{\prime \prime}} \equiv\left\{B P_{i}\right\} .
\end{gathered}
$$

In reality, the formation of the information system through a sequential selection of components results in inability to accomplish the last two expressions.

Among other things, there can be situations of mutual redundancy of the implemented components, and their partial redundancy and failure. The most common (and commonly occurring) case is the following:

$$
\left\{\begin{array}{l}
\bigcup_{j} B P_{i}^{j \prime \prime} \backslash\left\{B P_{i}\right\} \neq \varnothing \\
\left\{B P_{i}\right\} \backslash \bigcup_{j} B P_{i}^{j \prime \prime} \neq \varnothing,
\end{array}\right.
$$

when the implemented set of subsystems does not completely computerize all enterprise business processes, but along with this there are functions of the implemented subsystems which are not necessary in terms of information needs of the enterprise.

Functional insufficiency of the implemented subsystems is compensated by in-house developments, so we will consider the target information system as a set of purchased subsystems

$$
I S S b_{j}^{\prime \prime}=\left\{B P b_{i}^{j^{\prime \prime}}\right\}
$$

and developed subsystems

$$
I S S d_{k}^{\prime \prime}=\left\{B P d_{i}^{k \prime \prime}\right\}
$$

The automation activity should result in establishing an information system for which the following condition is to be met:

$$
\bigcup_{j} B P b_{i}^{j \prime \prime} \cup \bigcup_{k} B P d_{i}^{k \prime \prime} \supseteq\left\{B P_{i}\right\}
$$

The tasks of selecting purchased components and designing components being developed are actually limited to the problem of multi-criteria optimization in which specifically such hard-to-formalize variables as the degree of risk of introducing unpopular software systems, usability of a particular subsystem, etc. shall be considered.

\section{Structural model of information system management}

A structural model of the technological information system platform focused on solution of integration problems of legacy, developed and purchased components is proposed. Decomposition of functions performed by the system and function modules for storage, processing, data transmission and management functions [3], as well as the methodology of synthesis of firmware processor control devices lay the foundation for the proposed model tested by the authors in solution of a number of problems [4, 5].

The platform control module (CM) is formed per a known structure of the firmware processor control device [6] (Figure 1).

Let us call an analogue of the firmware program of the processor control unit (CU) a CM metaprogram. Just as the firmware program is a set of microcommands, and microcommands in turn are a set of microoperations, let us represent the metaprogram as a set of metacommands consisting of sub-operations. A command sent to $\mathrm{CM}$ contains an operation code (OC). A metacommand

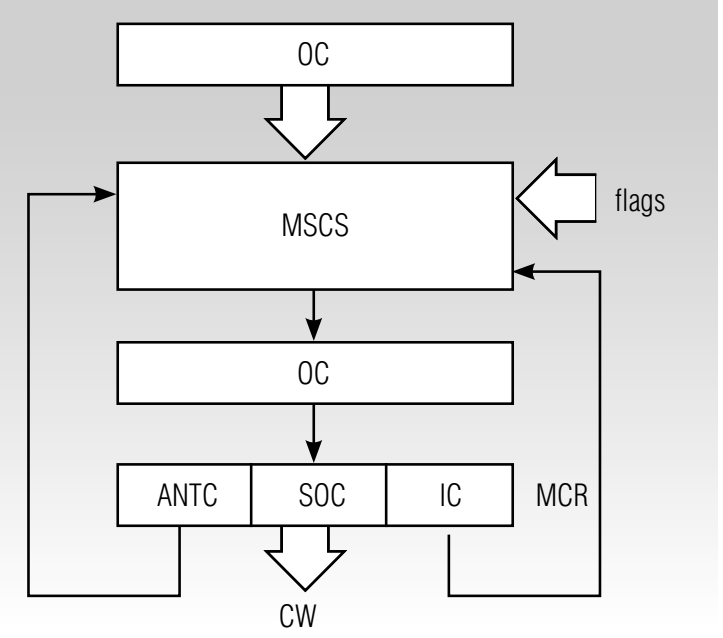

Fig. 1. Structure of CM for information system platform 
sequence controller (MCSC) selects a metacommand from the metacommand memory (MCM) and places it in the metacommand register (MCR). The metacommand consists of an address of the next metacommand (ANTC), sub-operation code (SOC), which generates a control word (CW) supplied to the processing module, as well as the identifier code (IC).

MCM is a metadata base. MCM is characterized by associativity (i.e. a possible memory call by values of various gadgets), and structural hierarchical pattern. MCM recording format:

$$
\begin{aligned}
\text { MetaCmd }= & <\text { MCCode, NextMCCode, SOCode, } \\
& \{<\text { ParName, ParDef }>\}>,
\end{aligned}
$$

where MCCode is a metacommand code;

NextMCCode is a code of the next metacommand;

SOCode is a sub-operation code;

ParName is a name of the sub-operation parameter;

ParDef is a description of the sub-operation parameter.

The sub-operation code in the existing implementation is represented by names of the executable results processing and visualization modules. The description of the sub-operation parameters includes a type of parameter, its minimum and maximum values, change step, etc. The integration of purchased and developed modules on the proposed platform is based on consistency of modules (1) and (2) start format with this description.

The instruction memory (IM), which similar to MCM has associativity and hierarchical structure, stores the operation code and parameters. The IM recording format is as follows:

$$
\begin{gathered}
\text { Op }=<\text { OpCode },\{<\text { MCCode },\{<\text { ParName } \\
\text { ParValue }>\}>\}>,
\end{gathered}
$$

where OpCode is an operation code;

MCCode is a metacommand code;

ParName is a name of sub-operation parameter;
ParValue is a value of a sub-operation parameter.

Figure 2 illustrates the operation of the instruction and metacommand memory controllers in the course of sampling instructions from the instruction memory and their processing.

For data processing automation, the instruction memory should be generated automatically by the processing planning module (scheduler). The scheduler work is based on the existing set of operations, accessible ranges of parameters for each sub-operation, processed data (specifically, metacommands and sub-operation parameters, execution of which resulted in obtaining available information units), and planned (present in the instruction memory) processing.

These data indicate that the data memory (DM) storing the data analysis results should also possess the properties of associativity and hierarchy. The data memory recording format:

$$
\begin{gathered}
\text { Data }=<\text { MCCode, }\{<\{<\text { ParName, ParValue }>\}, \\
\text { DataBlock }>\}>,
\end{gathered}
$$

where MCCode is a metacommand code;

ParName is the name of a sub-operation parameter;

ParValue is a value of the sub-operation parameter;

DataBlock is a data unit.

The operation of the combined instruction/metacommand memory controller, data memory controller and scheduler in the process of planning instructions and their entry into the instruction memory is provided in Figure 3.

\section{Use of an electronic document management system as a platform for applications integration in the enterprise information system}

One example of implementation of the structural model considered is the use of an electronic document management system (EDMS) as an integration platform [7,

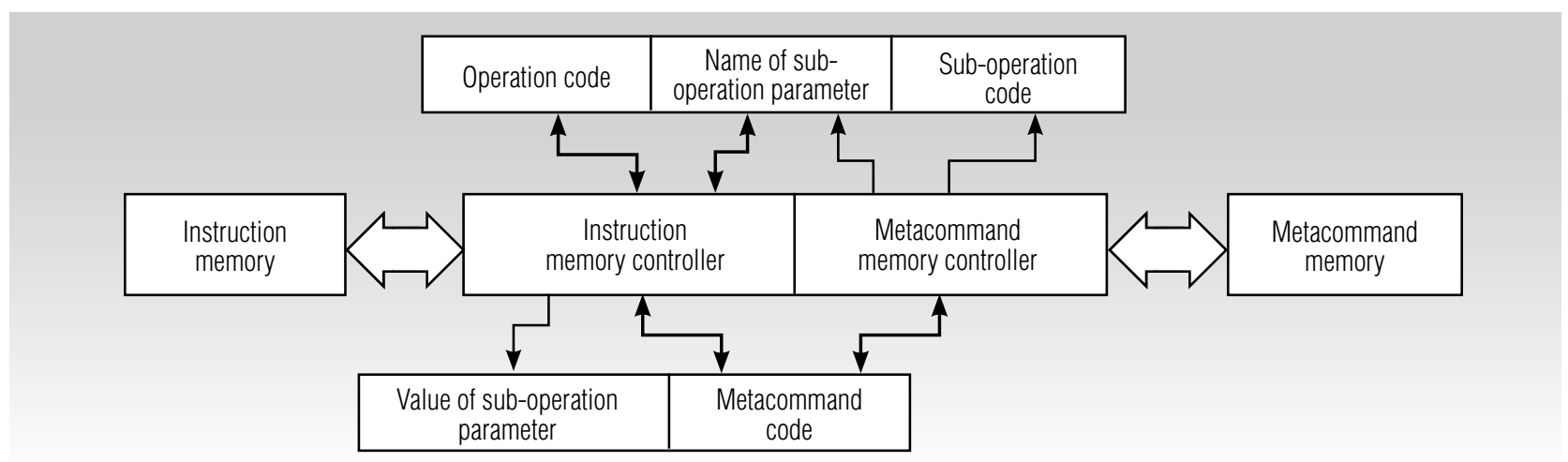

Fig. 2. Functionality of the instruction and metacommand memory controllers 


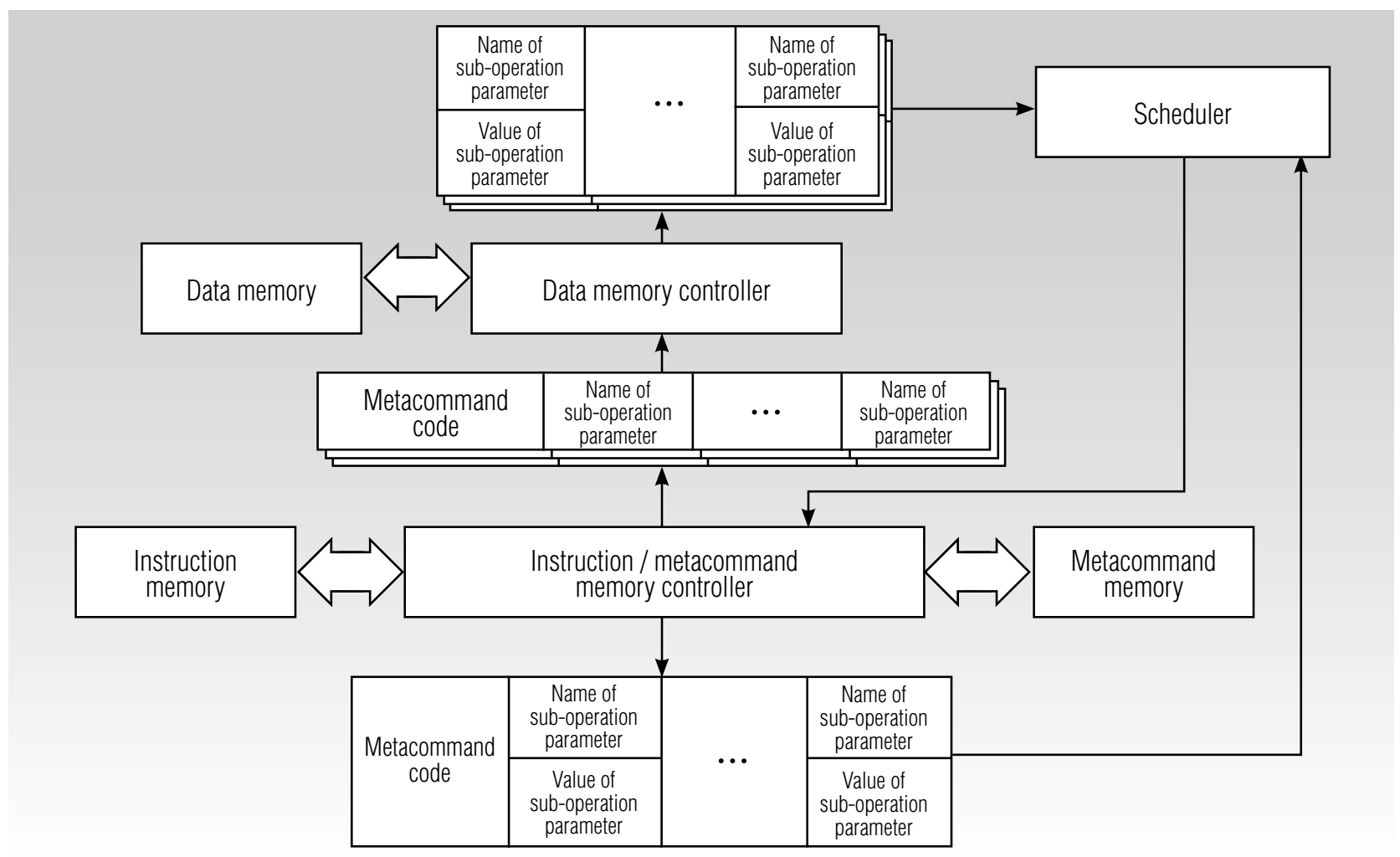

Fig. 3. Operation of the instruction/metacommand memory controller, data memory controller and scheduler

8], called in this case "SED-bus" providing an interaction of various systems (accounting, ERP, CAD, and others) via the document flow.

The experience of using EDMS at a large enterprise in accordance with the concept $[7,8]$ demonstrates a wide range of tasks for execution, including tasks of integration between the enterprise sub-systems:

1. Organization of fast network data exchange in electronic form within the enterprise, approved by an electronic signature. Use of information on observing the dates of document processing while generating reports which further makes it possible to improve performance discipline in taking management decisions and raises the overall efficiency of the enterprise.

2. Organization of exchange of all types of documents (including legally valid documents) with contracting parties and, therefore, acceleration of agreement of contracts, business correspondence, conclusion of transactions.

3. Extended handling of the help system used in various departments and software modules, limited by filtration and access rights appointed to roles (positions) or groups (departments). EDMS makes it possible to handle this reference information of the enterprise provided that EDMS manuals are synchronized with other systems in real time. These problems are solved within subsystems (2), which was addressed by the authors in a number of examples [2, 9]. The problems of integration are solved in a similar way using EDMS between the enterprise IS subsystems and an external IS.

4. The integration of EDMS with the accounting system, which resulted in ability to automatically start the document flow routes for approval or information distribution (documents or reports - accounting, legal, financial, relating to processing orders, works performed, payments made and shipped products).

5. Integration with budgeting, financial management, customer relationship management systems.

The use of standard EAI (Enterprise Application Integration) templates makes it possible to solve an unlimited number of problems within the problem area. The most famous EAI-solutions for integration of enterprise applications are IBM WebSphere MQ, Microsoft BizTalk Server, TIBCO, WebMethods, SeeBeyond, Vitria, Cross Worlds and others [1].

According to the EAI principle, while using the EDMSbus as an intermediate integration layer (middleware) of the enterprise it is preferable to use IS replicated patterns. For example, for EDMS operating as a platform for enterprise application integration organized in the form of guaranteed delivery of tasks (independent of the senders and receivers) according to business routes, a standard approach, namely messaging, has been used. 


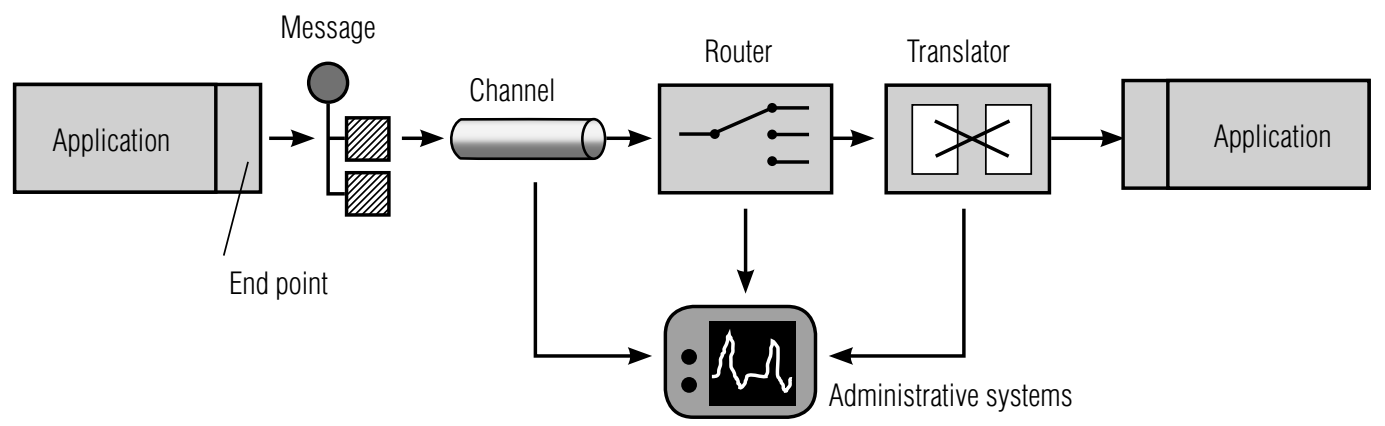

Fig. 4. Key elements of an integrated solution based on messaging [1]

Messaging in accordance with EAI concept is provided upon availability of a number of elements required for integrated solution (Figure 4).

When using the electronic document management system as a platform for application integration, the enterprise information system also uses a number of standard elements listed in Table 1.

\section{Key elements of the integrated solution based on EDMS-bus}

\begin{tabular}{|c|c|c|}
\hline Elements & $\begin{array}{l}\text { Purpose of element } \\
\text { according } \\
\text { to EAl provision }\end{array}$ & $\begin{array}{c}\text { ERP - EDMS - count- } \\
\text { ing system } \\
\text { integration }\end{array}$ \\
\hline $\begin{array}{l}\text { Application } \\
\text { (sender) }\end{array}$ & Platform & Informix ERP MAX+ \\
\hline $\begin{array}{l}\text { Sender } \\
\text { endpoint }\end{array}$ & $\begin{array}{c}\text { Component which publishes } \\
\text { a message in a message } \\
\text { channel }\end{array}$ & IBM Informix ODBC Driver \\
\hline $\begin{array}{c}\text { Message } \\
\text { (header, body) }\end{array}$ & $\begin{array}{l}\text { Smallest data unit transmit- } \\
\text { ted via a message channel }\end{array}$ & $\begin{array}{l}\text { Data is transmitted } \\
\text { as TCP/IP packets }\end{array}$ \\
\hline $\begin{array}{l}\text { Message } \\
\text { channel }\end{array}$ & $\begin{array}{l}\text { Channel of specific data } \\
\text { transmission }\end{array}$ & $\begin{array}{l}\text { Channel "point-to-point" } \\
\text { with asynchronous } \\
\text { message delivery to EDMS } \\
\text { based on MS SQL Server }\end{array}$ \\
\hline $\begin{array}{l}\text { Message } \\
\text { router }\end{array}$ & $\begin{array}{l}\text { Special filter which retrieves } \\
\text { a message from one mes- } \\
\text { sage channel and places into } \\
\text { another one (to control a load } \\
\text { in several queues) }\end{array}$ & None \\
\hline Translator & $\begin{array}{l}\text { A special filter for data } \\
\text { format conversion }\end{array}$ & $\begin{array}{c}\text { Conversion of data format } \\
\text { using SQL-type adapter }\end{array}$ \\
\hline $\begin{array}{c}\text { Receiver end } \\
\text { point }\end{array}$ & $\begin{array}{l}\text { Component enabling the ap- } \\
\text { plication to receive a message }\end{array}$ & $\begin{array}{l}\text { Microsoft FoxPro VFP } \\
\text { ODBC Driver }\end{array}$ \\
\hline $\begin{array}{l}\text { Application } \\
\text { (sender) }\end{array}$ & Platform & DBMS dBase VFP 9 \\
\hline
\end{tabular}

The use of messaging technology ensures the following advantages [1]:

$\uparrow$ platform and language integration (template is based on a message bus) - messaging system is responsible for data transmission;
\ asynchronous interaction ("sent and forgot", no simultaneous availability of the sender and receiver is required);

$\checkmark$ time mismatch (as opposed to synchronous, asynchronous interaction makes it possible to place and handle calls at different rates and without waiting for completion of their processing by the receiver);

$\downarrow$ load control of the transmission channel (flow control);

$\checkmark$ reliable interaction between applications (through approach with an intermediate storage);

$\checkmark$ interposition between interacting applications with various language environments.

The following disadvantages of the messaging model technology can be pointed out:

complicated programming model, which is split into numerous processing procedures;

$\diamond$ asynchronous interaction model is not suitable for all cases (including a need for implementing synchronous models);

$\diamond$ time and procedure of message delivery are not stipulated, so transmission delays are not excluded;

$\diamond$ significant time and resources consumed organizing corporate wide integration.

\section{Conclusion}

As can be seen from the above, the information model concerning the problem of forming the enterprise information system through integration of legacy, purchased and developed information subsystems was considered, the formal and theoretical basis of constructing integration platforms of the administrative-analytical systems was analyzed, and the structural model of the platform software was proposed. The implementation of the above principles of the middleware layer is possible by using modern electronic document management systems and standard templates of replicated applications for integration. 
The prospects of further research are to solve the problems of integration of enterprise information system taking into account a possible reconfiguration of the system and replacement of the existing modules and subsystems in the future driven by new requirements imposed by a changing economic environment.

\section{References}

1. Hohpe G., Wolf B. (2007) Shablony integratsii korporativnykh prilozhenii [Enterprise integration patterns]. Moscow: Williams (in Russian).

2. Lanskikh Yu.V., Bogomolova E.V., Tatarinova E.O. (2012) Reshenie zadach sistemnoj integracii pri avtomatizacii transportnogo ucheta v regionalnom predpriyatii svyazi [Meeting the challenges of system integration in the automation of vehicle accounting in the regional communications enterprise]. Proceedings of the International Scientific Conference "Regions in the Conditions of Unsustainable Development", 1-3 November 2012, Sharya - Kostroma. Vol. 2. P. 188-193 (in Russian).

3. Balashov E.P., Puzankov D.V. (1987) Proektirovanie informatsionno-upravlyayushchikh sistem [Design of management information systems]. Moscow: Radio and Communications (in Russian).

4. Lanskikh Yu.V. (2012) Principy organizacii texnologicheskoj platformy i procedur obrabotki dannyx v informacionno-analiticheskoj sisteme [Principles of organizing the technological platform and data processing procedures in the information-analytical system]. Herald of ITARK, no. 1, pp. 24-28 (in Russian).

5. Lanskikh Yu.V., Nechaev D.S. (2004) Organizaciya upravleniya v sistemax intellektualnogo analiza dannyx [Organization of data mining system control]. Herald of Vyatka Scientific Center. Series: Problems of Information Processing, no. 1 (5), pp. 144-149 (in Russian).

6. Balashov E.P., Grigoriev V.L., Petrov G.A. (1984) Mikro- $i$ mini-EVM [Micro- and mini-computers]. Leningrad: Energoatomizdat (in Russian).

7. Bogomolova E.V., Lanskikh Yu.V. (2014) Prakticheskie resheniya po ispol'zovaniyu sistemy elektronnogo dokumentooborota v informatsionnoi sisteme predpriyatiya [Practical solutions for using of an electronic document management system in the enterprise information system]. Proceedings of Annual Scientific and Practical Conference "Society, Science and Innovations". Section "Design of Data Processing and Data Presentation Systems”. 15-26 April 2014, Kirov. Available on CD-ROM, article no. 8 (in Russian).

8. Arif M., Kulonda D., Egbu C., Goulding J.S., Toma T. (2011) Enterprise-wide information system for construction: A document based approach. KSCE Journal of Civil Engineering, vol. 15, no. 2, pp. 271-280.

9. Bogomolova E.V., Lanskikh Yu.V. (2013) Prakticheskie resheniya po sinkhronizatsii spravochnoi informatsii v korporativnoi sisteme predpriyatiya [Practical solutions for synchronizing of reference information in an enterprise corporate system]. Proceedings of Annual Scientific and Practical Conference "Society, Science and Innovations". University-wide section. 15-26 April 2013, Kirov. Available on CD-ROM (in Russian).

\section{Решение задач интеграции \\ в информационных системах управления предприятием}

\section{B.Ю. Вахрушев}

кандидат технических наук, декан факультета автоматики и вычислительной техники

Вятский государственный университет

Адрес: 610000, г. Киров, ул. Московская, д. 36

E-mail:vahrushev@vyatsu.ru

\section{Е.В. Богомолова}

ведуший инженер-программист ОАО ЭМСЗ «ЛЕПСЕ»

аспирант кафедры автоматики и телемеханики, Вятский государственный университет

Адрес: 610000, г. Киров, ул. Московская, д. 36

E-mail:elenaoops@mail.ru

\section{A.M. Ланских}

кандидат технических наук, доцент кафедры автоматики и телемеханики

Вятский государственный университет

Адрес: 610000, г. Киров, ул. Московская, д. 36

E-mail: usr00221@vyatsu.ru

\section{Ю.В. Ланских}

кандидат технических наук, доцент кафедры автоматики и телемеханики

Вятский государственный университет

Адрес: 610000, г. Киров, ул. Московская, д. 36

E-mail:lyuv@inbox.ru

\section{A.B. Луппов}

кандидат технических наук, доцент кафедры автоматики и телемеханики

Вятский государственный университет

Адрес: 610000, г. Киров, ул. Московская, д. 36

E-mail:dei123@mail.ru 


\section{А.В. Малышева}

преподаватель кафедры автоматики и телемеханики

Вятский государственный университет

Адрес: 610000, г. Киров, ул. Московская, д. 36

E-mail: annyml@mail.ru

\section{Н.А. Шмакова}

старший преподаватель кафедры автоматики и телемеханики

Вятский государственный университет

Адрес: 610000, г. Киров, ул. Московская, д. 36

E-mail: shmakova.natalya@mail.ru

\section{Аннотация}

Авторы рассматривают проблематику построения информационных систем учета, управления и анализа деятельности предприятия. Один из наиболее экономически целесообразных путей построения таких систем интеграция унаследованных, приобретаемых и разрабатываемых компонентов на базе программного обеспечения промежуточного уровня, которое может быть квалифицировано как технологическая платформа интеграции.

Рассматривается формализация принципов построения такого платформенного программного обеспечения. Эти принципы формируются по аналогии с принципом формирования микропрограммного управляющего устройства процессора. В работе показано, как, используя микропрограммное устройство управления процессором в качестве формальной модели, разработать программную платформу, позволяющую организовать запуск процедур обработки, визуализации и обмена данными по расписанию или запросу пользователя. Совокупность информационно-программного обеспечения, играющего роль платформы, декомпозируется на память инструкций, память метакоманд, контроллер памяти инструкций и контроллер памяти метакоманд.

В качестве одного из вариантов платформенного программного обеспечения рассматривается система управления документооборотом. Указано на возможность использования системы электронного документооборота для обмена информацией, защищенной электронной цифровой подписью, а также интеграции информационных подсистемам справочного, учетного и прочих назначений. Такая практика получила название СЭД-шины.

В рамках теоретической постановки задачи рассматривается информационная модель предметной области как совокупность выполняемых в ней бизнес-процессов. Автоматизация деятельности в предметной области заключается в формировании множества автоматизированных бизнес-процессов (мощность которого определяется функциональностью внедряемой информационной системы), максимально покрывающего множество бизнес-процессов предметной области. Рассматриваются случаи совмещения множеств бизнеспроцессов унаследованных информационных систем и бизнес-процессов внедряемых информационных систем.

Ключевые слова: система управления предприятием, информационная модель, система электронного документооборота, микропрограммное устройство управления, бизнес-процесс, промежуточный программной слой.

Цитирование: Vahrushev V.Yu., Bogomolova E.V., Lanskih A.M., Lanskih Yu.V., Luppov A.V., Malysheva A.V., Shmakova N.A. Solution of integration tasks in enterprise management information systems // Business Informatics. 2016.

No. 1 (35). P. 37-44. DOI: 10.17323/1998-0663.2016.1.37.44.

\section{Литература}

1. Хоп Г., Вульф Б. Шаблоны интеграции корпоративных приложений. М.: Вильямс, 2007. 672 с.

2. Ланских Ю.В., Богомолова Е.В., Татаринова Е.О. Решение задач системной интеграции при автоматизации транспортного учета в региональном предприятии связи // Материалы международной научной конференции «Регионы в условиях неустойчивого развития» (1-3 ноября 2012 г., Шарья - Кострома): в 2 т. - Т. 2 / Сост. А.М. Базанков, И.Г. Криницын, А.П. Липаев. - Кострома: КГУ им. Н.А. Некрасова, 2012. С. $188-193$.

3. Балашов Е.П., Пузанков Д.В. Проектирование информационно-управляющих систем. М.: Радио и связь, 1987. 256 с.

4. Ланских Ю.В. Принципы организации технологической платформы и процедур обработки данных в информационноаналитической системе // Вестник ИТАРК. 2012. №1. С. 24-28.

5. Ланских Ю.В., Нечаев Д.С. Организация управления в системах интеллектуального анализа данных // Вестник Вятского научного центра Верхне-Волжского отделения АТН РФ. Серия: Проблемы обработки информации. 2004. № 1 (5). С. 144-149.

6. Балашов Е.П., Григорьев В.Л., Петров Г.А. Микро- и мини-ЭВМ. - Л.: Энергоатомиздат. Ленинградское отделение, 1984. 376 с.

7. Богомолова Е.В., Ланских Ю.В. Практические решения по использованию системы электронного документооборота в информационной системе предприятия // Всероссийская ежегодная научно-практическая конференция «Общество, наука, инновации» (НПК-2014). Секция «Вопросы проектирования систем обработки и представления данных». 15-26 апреля 2014 г., Киров: Сб. материалов. Киров, 2014. 1 электрон. опт. диск (CD-ROM).

8. Enterprise-wide information system for construction: A document based approach / M. Arif [et al.] // KSCE Journal of Civil Engineering. 2011. Vol. 15. No. 2. P. 271-280.

9. Богомолова Е.В., Ланских Ю.В. Практические решения по синхронизации справочной информации в корпоративной системе предприятия // Всероссийская ежегодная научно-практическая конференция «Общество, наука, инновации» (НПК-2013). Общеуниверситетская секция, БФ, ГФ, ФЭМ, ФАВТ, ФАМ, ФПМТ, ФСА, ХФ, ЭТФ. 15-26 апреля 2013 г., Киров: Сб. материалов / отв. ред. С.Г. Литвинец. - Киров, 2013. 1 электрон. опт. диск (CD-ROM). 